\title{
Campus and Online U.S. College Students' Attitudes Toward an Open Educational Resource Course Fee: A Pilot Study
}

\author{
Brian L Lindshield ${ }^{1} \&$ Koushik Adhikari ${ }^{1}$ \\ ${ }^{1}$ Department of Human Nutrition, Kansas State University, Manhattan, Kansas, 66506, USA \\ Correspondence: Brian Lindshield, 208 Justin Hall, Manhattan, KS, 66506, USA. Tel: 1-785-532-7848. E-mail: \\ blindsh@k-state.edu
}

Received: September 9, 2013

Accepted: September 23, $2013 \quad$ Online Published: September 27, 2013

doi:10.5430/ijhe.v2n4p42

URL: http://dx.doi.org/10.5430/ijhe.v2n4p42

\begin{abstract}
Convincing faculty to accept, create, adapt, and adopt open educational resources (OERs) instead of textbooks for their courses has proven challenging because incentives are lacking. One approach to provide incentive to faculty members is an OER course fee, which could be employed in courses that use OERs approved by the institution for courses that do not utilize textbooks or other resources students must purchase. This fee would provide sustained incentive for using OERs while also decreasing student expense compared with what most currently pay for textbooks. We set out to determine if campus and online students who had used a free OER textbook replacement would support the idea, and implementation at their institution, of an OER course fee. Among online students $(\mathrm{n}=$ 17), those who supported an OER course fee at their institution $(n=6)$ the mean appropriate course fee amount was $\$ 9.58$ /credit hour. Subsequent campus $(n=46)$ and online students $(n=57)$ were asked whether they supported a $\$ 10 /$ credit hour OER course fee, greater than $67 \%$ of somewhat agreed, agreed, or strongly agreed. While these pilot results are encouraging, it is important to note that they are from one course, using one OER, by one instructor at one institution. More research is needed to determine if there is similar support for OER course fees in a broader base of students. If so, OER course fees may be a legitimate approach to increase the acceptance, creation, adaptation, and adoption of OER.
\end{abstract}

Keywords: Open educational resource, Fee, Textbook, Etextbook, Open access, Flexbook, Open source, Online

\section{Introduction}

Open educational resources (OERs) are "educational materials that are either (a) licensed under an open copyright license (e.g., Creative Commons) or (b) in the public domain" and as a result can be accessed for free and revised, remixed, reused, and redistributed by others (Wiley \& Green, 2012). OERs were the number one technology that students indicated they wished instructors used more in a 2012 survey (Dahlstrom, 2012). Despite the tremendous potential of OERs, "they have not noticeably disrupted the traditional business model of higher education or affected daily teaching approaches at most institutions (Kortenmeyer, 2013)."

Some OERs can be used to replace textbooks, and individual faculty members are the primary decision-makers on whether to adopt them (Allen \& Seaman, 2012); however, most faculty do not consider OERs as alternatives to textbooks when deciding what resource(s) to use in their course(s) (Morris-Babb \& Henderson, 2011). Faculty have indicated that barriers to the production of OERs include no reward for time or energy invested and no support from administration (Humbert, 2008). In addition, faculty do not think that most institutions have fair systems for rewarding digital pedagogy (Allen \& Seaman, 2012).

On the other hand, faculty have indicated that the biggest incentives to produce OERs are financial reward and acknowledgement as the OER's creator (Humbert, 2008). Faculty members will most likely require incentive to change from textbooks to OERs. One way to provide incentive is through grants to faculty members to create, adapt, and/or adopt OERs in place of textbooks. Examples of this approach include The Alternative Textbook Project at Temple University, The Open Education Initiative at the University of Massachusetts at Amherst, the University of Minnesota Open Education Initiative, and The Open/Alternative Textbook Initiative at Kansas State University. Although these are excellent initiatives, their impact is constrained by available funding. Another problem is limited incentive for faculty to invest the time required to maintain, revise, update, and/or customize the OER after the initial grant period. 
An alternative approach is an OER course fee for OERs that meet certain quality criteria. This fee would apply only for courses that use OERs without using textbooks or other resources that students must purchase. An OER course fee would provide incentive not only to adopt, but also to maintain, revise, update, and/or customize OERs by rerouting some of the funds students pay for textbooks into institutions. The fee would be expected to be lower than what most students pay for textbooks now, thereby reducing student expense, and would give students input through student governance into how much they pay and how revenue is used, unlike current textbook purchases. Policies around this fee would need to be established, but one example of a similar approach with an etextbook has been published (Baker-Eveleth, Miller, \& Tucker, 2011).

We set out to determine if students who have used an OER textbook replacement, the Kansas State University Human Nutrition (HN 400) Flexbook, free of charge, would support the idea of an OER course fee to increase the adoption of OERs to replace textbooks. Information about the course, the flexbook, and students' use and perception of it has been described previously (Lindshield \& Adhikari, 2011; Lindshield \& Adhikari, 2013). We hypothesized that campus and online students would support the idea of an OER course fee because it would be less expensive than what many pay now for textbooks.

\section{Method}

Approval for both surveys was obtained from the Kansas State University Institutional Review Board.

\subsection{OER Course Fee Pilot Survey}

The survey used branching logic and included 6 demographic questions, a question about respondents' perceived tech savviness, a question about whether respondents would support the idea of an OER course fee, and a question about whether respondents would support an OER course fee at their institutions. Students who answered "no" to supporting an OER course fee at their institution question were branched to the final two open-ended questions that asked why they supported or did not support an OER course fee and another that asked for additional feedback on the idea of an OER course fee. Students who answered "yes" or were neutral to supporting an OER course fee at their institution were directed to a question about an appropriate amount for an OER course fee and an open-ended question in which they could explain the reason for the amount they chose. They were then directed to the same final two open-ended questions. The non-demographic questions from this survey can be found in Supplementary Material A. Late in the summer 2012 semester, emails with unique links to an anonymous survey were sent to online students who had been using an OER, the Kansas State University Human Nutrition (HN 400) Flexbook. The Axio Survey platform sent one reminder email during the two and a half weeks that the survey was available for students to complete. The instructor invited online students to take the survey and reminded them using announcements on the campus course management system.

\subsection{OER Course Fee Survey}

The survey was the same as the pilot survey except for these changes: The two questions about the amount of the OER course fee and reason for choosing it were removed, $\$ 10 /$ credit hour was added to the questions about the idea of the OER course fee and an OER course fee at respondents' institutions, and these questions were changed to use Likert disagree/agree scales. Language was also added to clarify that the fee would be charged only for courses using OERs approved by a university committee that includes students. The non-demographic questions from this survey can be found in the Supplementary Material B. Late in the fall 2012 (online) and spring 2013 (campus and online) semesters, emails with unique links to an anonymous survey were sent to students who had been using an OER, the Kansas State University Human Nutrition (HN 400) Flexbook. The Axio Survey platform sent two reminder emails during the two and a half weeks that the survey was available for students to complete. The instructor invited and reminded campus students about the survey in class, invited online students using an announcement on the campus course management system, and reminded both campus and online students through announcements on the course management system.

\subsection{Data Analysis}

OER course fee survey response rate percentages and means \pm standard error of the mean for Likert questions were calculated from survey responses, and Mann-Whitney-Wilcoxon tests were performed using SAS 9.3 (SAS Institute Inc., Cary, North Carolina), with $\mathrm{p}<0.05$ considered significant between online and campus students. 


\section{Results}

\subsection{OER Course Fee Pilot Survey}

Forty-six percent (17/37) of online students completed the survey. Demographic questions indicated that a majority of the students who completed the survey were female dietetics majors. When asked if they considered themselves tech-savvy, 82\% (14/17) somewhat agreed, agreed, or strongly agreed.

The most common response about whether students liked the idea of a OER course fee was yes, but students who were neutral or against the idea were also well represented (Table 1). When we asked if students would support an OER course fee at their college or university, neutral was the most common response, followed by yes, then no.

Table 1. Online student responses about the idea of an OER course fee, and an OER fee at their institution

\begin{tabular}{lccc}
\hline & Yes & No & Neutral \\
\hline $\begin{array}{l}\text { Do you think a student fee to encourage the development and adoption of OERs, such as the } \\
\text { flexbook, in more courses is a good idea? }\end{array}$ & 8 & 4 & 5 \\
$\begin{array}{l}\text { Would you support a student fee to encourage the development and adoption of OERs, such } \\
\text { as the flexbook, in more courses at your college or university? }\end{array}$ & 6 & 3 & 8 \\
\hline
\end{tabular}

Students who answered yes or neutral to whether they would support an OER course fee most commonly responded that $\$ 2.50$ or $\$ 5 /$ credit hour was an appropriate amount for an OER course fee (Table 2). Respondents who were neutral about the OER course fee at their college or university chose a lower fee (mean \$4.06) than students who supported an OER course fee (mean \$9.58).

Table 2. The dollar amount/credit hour that online students thought appropriate for an OER course fee

\begin{tabular}{lcccccc}
\hline Per credit hour & $\$ 2.50$ & $\$ 5$ & $\$ 7.50$ & $\$ 10$ & $\$ 12.50$ & $\$ 15$ \\
Number of students & 5 & 4 & 1 & 2 & 0 & 2 \\
\hline
\end{tabular}

3.1.1 Pilot survey open-ended questions

Ten students answered an open-ended question about their reasoning for choosing their fee amount in the previous question. One student supported the $\$ 15$ fee in his/her response, two stated that $\$ 10 /$ credit hour was reasonable, and another indicated that he/she was willing to pay any of the fee options. One student each wrote supporting the $\$ 7.50$ and $\$ 5 /$ credit hour fees. One student indicated that he/she worried about an across-the-board fee where students would be paying the fee while also having to buy a textbook for the course.

Eleven students responded to a question about the reason they supported or did not support an OER course fee. Two students indicated that they supported the fee because they liked the flexbook's convenience and features. Three students indicated that they supported the fee; another student indicated he/she supported it only if it was for courses that used the OER, and another supported the fee only if it was not too expensive. One student was neutral, and two were against the fee. Another indicated liking physical textbooks and the supplemental features they provide.

Four students answered the final question that asked for additional feedback on the idea of the OER course fee. Three students indicated support for the fee and indicated that they liked using the flexbook. Another asked if OERs could be approved before a course fee is assessed to students. This student wanted some quality control procedures in place to make sure that students would be getting a quality product.

\subsection{Changes Made to Survey Based on Pilot Survey Results}

Based on the results of this pilot survey, it became clear that we needed to provide more background information about how the proposed OER course fee would be administered. In the new survey, we added language to inform students that the fee would be only for courses using OERs and that a university committee including students would approve the OERs before the fee would be assessed to a course using them. Little justification was provided for the lowest two credit hour fee levels in the open-ended question; thus we decided to determine if students would support a $\$ 10 /$ credit hour OER course fee because it was near the mean of students who supported an OER course fee at their institution.

\subsection{OER Course Fee Survey}

\subsubsection{Demographics}

Table 3 shows the demographics of survey respondents. As we found previously (Lindshield \& Adhikari, 2011; Lindshield \& Adhikari, 2013), online students were older than campus students and were predominately female dietetic majors. 
Table 3. Demographics of surveyed campus and online students

\begin{tabular}{|c|c|c|}
\hline & $\begin{array}{l}\text { Campus } \\
(n=46)\end{array}$ & $\begin{array}{l}\text { Online } \\
(n=57)\end{array}$ \\
\hline \multicolumn{3}{|c|}{ Age } \\
\hline $18-25$ years & 43 & 25 \\
\hline $26-35$ years & 2 & 23 \\
\hline $36-45$ years & 1 & 5 \\
\hline$\geq 46$ years & 0 & 4 \\
\hline \multicolumn{3}{|c|}{ Gender } \\
\hline Female & 36 & 49 \\
\hline Male & 10 & 8 \\
\hline \multicolumn{3}{|c|}{ Traditional student } \\
\hline Yes & 41 & 23 \\
\hline No & 5 & 34 \\
\hline \multicolumn{3}{|c|}{ Classification $^{\mathrm{a}}$} \\
\hline Freshman & 1 & 0 \\
\hline Sophomore & 7 & 4 \\
\hline Junior & 24 & 8 \\
\hline Senior & 5 & 5 \\
\hline Senior-plus & 4 & 6 \\
\hline \multicolumn{3}{|c|}{ Highest level of education ${ }^{\mathrm{b}}$} \\
\hline Some undergraduate education & 2 & 8 \\
\hline Associates degree & 0 & 10 \\
\hline Bachelor's degree & 1 & 12 \\
\hline Some graduate education & 0 & 0 \\
\hline Graduate degree & 2 & 4 \\
\hline \multicolumn{3}{|c|}{ Major/area of emphasis/study } \\
\hline Dietetics & 14 & 35 \\
\hline Public health nutrition & 14 & 10 \\
\hline Nutrition and kinesiology & 4 & 2 \\
\hline Athletic training & 5 & 1 \\
\hline Nutritional sciences & 6 & 3 \\
\hline Biology & 3 & 5 \\
\hline Kinesiology & 1 & 4 \\
\hline Life sciences & 3 & 2 \\
\hline Other & 6 & 4 \\
\hline
\end{tabular}

\footnotetext{
${ }^{a}$ Traditional students-only question, ${ }^{b}$ Nontraditional students-only question
}

\subsubsection{Survey response rate}

Survey response rates are shown in Table 4. A significantly higher percentage of online than campus students completed the survey.

Table 4. Total and semester survey response rates (\%)

\begin{tabular}{ccc}
\hline Semester & Campus & Online \\
\hline Fall 2011 & N/A & $30 / 52(57.7)$ \\
Spring 2012 & $46 / 118(39)$ & $27 / 50(54)$ \\
Total & $46 / 118(43.1)$ & $57 / 102(55.9)^{*}$ \\
\hline \multicolumn{3}{c}{$* p<0.001$ vs. campus students }
\end{tabular}




\subsubsection{Likert questions}

No significant differences were observed between campus and online students for the 3 Likert questions. When asked if they considered themselves tech-savvy, 67.4\% (31/46) and 80.7\% (46/57) of campus and online students, respectively, somewhat agreed, agreed, or strongly agreed. When asked if they supported the idea of an OER course fee, $71.8 \%$ of campus students somewhat agreed, agreed, or strongly agreed, compared with $19.5 \%$ who somewhat disagreed, disagreed, or strongly disagreed (Table 5). Similar to the results for campus students, $73.7 \%$ of online students somewhat agreed, agreed, or strongly agreed, whereas $19.3 \%$ somewhat disagreed, disagreed, or strongly disagreed that they supported the idea of an OER course fee. When asked if they would support an OER course fee at their college or university, $67.5 \%$ somewhat agreed, agreed, or strongly agreed, compared with $21.7 \%$ who somewhat disagreed, disagreed, or strongly disagreed. Again similar to campus students, $71.9 \%$ of online students somewhat agreed, agreed, or strongly agreed, whereas $19.3 \%$ somewhat disagreed, disagreed, or strongly disagreed that they would support an OER course fee at their college or university.

Table 5. Campus and online students' support for an open education resource (OER) course fee (\%)

\begin{tabular}{ccccc}
\hline & \multicolumn{2}{c}{ OER course fee survey idea } & \multicolumn{2}{c}{ OER course fee at institution } \\
\hline Choice & Campus & Online & Campus & Online \\
& $(\mathrm{n}=46)$ & $(\mathrm{n}=57)$ & $(\mathrm{n}=46)$ & $(\mathrm{n}=57)$ \\
Strongly disagree & $2(4.3)$ & $4(7.0)$ & $2(4.3)$ & $4(7.0)$ \\
Disagree & $1(2.2)$ & $5(8.8)$ & $4(8.7)$ & $4(7.0)$ \\
Somewhat disagree & $6(13.0)$ & $2(3.5)$ & $4(8.7)$ & $3(5.3)$ \\
Neither agree or disagree & $4(8.7)$ & $4(7.0)$ & $5(10.9)$ & $5(8.8)$ \\
Somewhat agree & $12(26.1)$ & $11(19.3)$ & $13(28.3)$ & $10(17.5)$ \\
Agree & $12(26.1)$ & $19(33.3)$ & $13(28.3)$ & $19(33.3)$ \\
Strongly agree & $9(19.6)$ & $12(21.1)$ & $5(10.9)$ & $12(21.1)$ \\
\hline
\end{tabular}

\subsubsection{Open-ended question responses}

Campus and online students had similar responses to the open-ended questions, so the results will be described together. Forty-one campus and 41 online students responded to the question asking why they supported or did not support the idea of an OER student fee. Twenty-seven campus and 27 online students responded that they were in favor of the fee because they liked the flexbook, thought the fee would save students money, and/or liked some of the advantages of OERs such as customization and their ability to be updated. One online student was on the fence, being for the fee only if it was for classes that used OERs, but against an across-the-board fee. Another campus student indicated feeling conflicted about wanting to support the fee but still liking traditional textbooks.

One online and five campus students were against the fee because they thought it was an across-the-board fee. An online student said he/she would support it only for certain instructors and another online student said only if it was for the HN 400 Flexbook. A campus student indicated that he/she would support the fee only for courses in which OERs replaced textbooks. One online and two campus students did not support the fee because thought they could buy and sell back textbooks at a lower cost than the fee amount. Similarly, one online and one campus student did not support the fee because they thought they could rent books for about the fee amount. One online and one campus student indicated that the cost per credit hour was too high for them to support. Two students were against the fee because they did not think there was much work involved for instructors because resources are already available. Similarly, another online student thought creating an OER was part of an instructor's duties, and that faculty should not be paid extra for doing it. Two online students and one campus student indicated not supporting the fee because of the cost they incurred printing the flexbook, and two online students gave brief comments indicating they were against the fee. One campus student indicated being hesitant to rely on technology to access OERs. Four online and four campus students answered the additional information question, but the responses only expounded on their statements in the previous question.

\section{Discussion}

This pilot study sought to determine whether online and campus students using a free OER would support the idea and implementation of an OER course fee to provide incentive for faculty to replace textbooks with OERs. If the OER course fee were widely utilized at an institution, it would be expected that most students would save money compared with what they currently spend on textbooks. Our findings that a majority of online and campus students support the idea of an OER course fee and its implementation at their institution supports our hypothesis. Given the differences in demographics and differences found in use and perception of the flexbook (Lindshield \& Adhikari, 2011; Lindshield \& Adhikari, 2013), it was surprising that the responses were so similar between online and campus students. From answers to the open-ended questions, it was clear that some students did not understand that the proposed OER course 
fee is only for courses that use OERs and not an across-the-board fee; this may indicate that the background students were given about the OER course fee was insufficient or that they did not read it before providing their answers.

Baker-Eveleth et al. (2011) described the publication of an instructor-written economics etextbook for a 4-credit-hour course at the University of Idaho for which students were charged a $\$ 51$ course fee. This amount was chosen because it was half the price of a used textbook for the course (Baker-Eveleth et al. 2011). It is worth noting that this is similar to the amount that students would contribute to a $\$ 10$ /credit hour OER course fee. Policies about how revenue from this fee would be distributed would need to be established, but clearly some of the revenue should go to the instructor. A couple of questions would have to be addressed in these policies: 1) would equal revenue distribution be the same for large enrollment and small enrollment courses?, and 2) would revenue distribution be the same for instructor-created and non-instructor-created OERs? Baker-Eveleth et al. (2011) report that for the first 3 years, $60 \%$ of revenue went to the author and $40 \%$ to a teaching center, with the institution levying a $6 \%$ tax. After three years, $90 \%$ of the revenue would go to the author and 10\% to the teaching center (Baker-Eveleth et al. 2011). In addition, policies related to the resources that qualified for the course fee also would need to be established; for instance, would such a fee be assessed for resources that are not open, like the Baker-Eveleth etextbook? This would be important to consider, because copyright issues may make OER creation for some courses difficult. If most of the resources developed are closed, however, although student expense at that institution would decrease, possible synergy between institutions from making the resources open is unlikely to occur. Finally, criteria for what constitutes a quality OER would need to be established.

This pilot study had several limitations that should be noted. First, the results are from a one course, using one OER, by one instructor at one institution. Changing even one of these variables might change the survey results. The sample size is also small, and we cannot rule out that students who completed the survey support the idea of an OER course fee more than those who did not complete it. We have also not established the validity of the survey, because it has been administered only to students in this one course.

More research is needed to determine if there is similar support for OER course fees in a broader base of students and faculty. If so, OER course fees may be a legitimate approach to increase the acceptance, creation, adaptation, and adoption of OER.

\section{Acknowledgements}

This is contribution no. 13-369-J from the Kansas Agricultural Experiment Station.

\section{References}

Allen, I. E., \& Seaman, J. (2012). Growing the curriculum: Open education resources in U.S. higher education. 1-42. [Online] Available: http://www.onlinelearningsurvey.com/reports/growingthecurriculum.pdf

Baker-Eveleth, L. J., Miller, J. R., \& Tucker, L. (2011). Lowering business education cost with a custom professor-written online text. Journal of Education for Business, 86(4), 248-252. http://dx.doi.org/10.1080/08832323.2010.502911

Dahlstrom, E. (2012). The ECAR study of undergraduate students and information technology. Louisville, CO: EDUCAUSE Center for Applied Research. [Online] Available: http://net.educause.edu/ir/library/pdf/ERS1208/ERS1208.pdf

Humbert, M. (2008). Open educational resources for management education: Lessons from experience. ELearning Papers, (10). [Online] Available: http://www.elearningeuropa.info/files/media/media16676.pdf

Kortemeyer, G. (2013). Ten years later: Why open educational resources have not noticeably affected higher education, and why we should care. EDUCAUSE Review Online. [Online] Available: http://www.educause.edu/ero/article/ten-years-later-why-open-educational-resources-have-not-noticeably-affect ed-higher-education-and-why-we-should-ca

Lindshield, B. L.; Adhikari, K. (2011) The Kansas State University Human Nutrition (HN 400) Flexbook. EDUCAUSE Review Online. [Online] Available: http://www.educause.edu/ero/article/kansas-state-university-human-nutrition-hn-400-flexbook

Lindshield, B. L.; Adhikari, K. (2013) Online and Campus College Students Like Using an Open Educational Resource Instead of a Traditional Textbook. MERLOT Journal of Online Learning and Teaching, 9(1), 26-38.

Morris-Babb, M., \& Henderson, S. (2011). An experiment in open-access textbook publishing: Changing the world one textbook at a time. Journal of Scholarly Publishing, 43(2), 148-155. http://dx.doi.org/10.3138/jsp.43.2.148

Wiley, D., \& Green, C. (2012). Why openness in education? In D. G. Oblinger (Ed.), Game changers: Education and information technologies (pp. 81-89) EDUCAUSE. [Online] Available: http://www.educause.edu/library/resources/chapter-6-why-openness-education 


\section{Supplementary Material A. Non-demographic OER course fee pilot survey questions}

Question 1

I consider myself technology savvy.

Strongly disagree

Disagree

Somewhat disagree

Neither agree or disagree

Somewhat agree

Agree

Strong Agree

Question 2

Open Educational Resource (OER) Student Fee Background Information

-The flexbook is an example of an Open Educational Resource (OER). OERs are available online and are free for faculty and students to use. OERs are being developed by individual faculty members; groups of individuals, companies like Flat World Knowledge (http://www.flatworldknowledge.com//*), and the University of Minnesota recently released Open Academics (https://open.umn.edu/opentextbooks/) which is a catalog of OERs.

-OERs offer the possibility of replacing textbooks in courses and reducing student expense.

-But for faculty it is more work to develop or adopt OERs instead of textbooks. Thus, the idea of a student fee has been proposed that would provide incentive for colleges and universities to encourage faculty to develop and adopt OERs.

-The idea is that the fee would be much lower than what students pay for most textbooks now, and provide for wider adoption of OERs by instructors, and thus lower student expense.

Do you think a student fee to encourage the development and adoption of OERs, such as the flexbook, in more courses is a good idea?

Yes

No

Neutral 
Question 3

Would you support a student fee to encourage the development and adoption of OERs, such as the flexbook, in more courses at your college or university?

Yes

No

Neutral

Students that answered yes or neutral to the previous question, answered the following 2 questions:

\section{Question 4}

Please select which of the following you think is an appropriate amount for the OER student fee?

$\$ 2.50$ /credit hour, $\$ 7.50$ for 3 credit hour course

$\$ 5 /$ credit hour, $\$ 15.00$ for 3 credit hour course

$\$ 7.50$ /credit hour, $\$ 22.50$ for 3 credit hour course

$\$ 10 /$ credit hour, $\$ 30$ for 3 credit hour course

$\$ 12.50$ /credit hour, $\$ 37.50$ for 3 credit hour course

$\$ 15 /$ credit hour, $\$ 45.00$ for 3 credit hour course

Question 5

What is your reasoning for choosing the student OER fee amount you did in the previous question?

Students that answered no to question 4, and those who completed questions 5 and 6 were asked these questions:

Question 4 or 6

What is the reason that you support or do not support a student fee to encourage the development and adoption of OERs?

Question 5 or 7

If you have additional feedback on the idea of OER student fee that you'd like to provide, please use the space below.

*At the time of this survey, Flat World Knowledge produced OER. That is no longer the case. 


\section{Supplementary Material B. Non-demographic OER course fee survey questions}

Question 1

I consider myself technology savvy.

Strongly disagree

Disagree

Somewhat disagree

Neither agree or disagree

Somewhat agree

Agree

Strong Agree

Question 2

Open Educational Resource (OER) Student Fee Background Information

-The flexbook is an example of an Open Educational Resource (OER). OERs are available online and are free for faculty and students to use. OERs are being developed by individual faculty members; groups of individuals, companies like Flat World Knowledge (http://www.flatworldknowledge.com/)*, and the University of Minnesota recently released Open Academics (https://open.umn.edu/opentextbooks/) which is a catalog of OERs.

-OERs offer the possibility of replacing textbooks in courses and reducing student expense.

-But for faculty it is more work to develop or adopt OERs instead of textbooks. Thus, the idea of a student fee has been proposed that would provide incentive for colleges and universities to encourage faculty to develop and adopt OERs.

-The idea is that the fee would be much lower than what students pay for most textbooks now, and provide for wider adoption of OERs by instructors, and thus lower student expense.

-An OER would have to meet certain criteria and be approved by a University committee that includes students, to assure it is of high quality, before the fee would be assessed only to students in the course using that OER.

In general, I support the idea of a $\$ 10 /$ credit hour student fee to encourage the development and adoption of OERs, such as the flexbook, in more courses.

Strongly disagree

Disagree

Somewhat disagree

Neither agree or disagree

Somewhat agree

Agree 
Strongly agree

Question 3

I support the idea of a $\$ 10 /$ credit hour student fee to encourage the development and adoption of OERs, such as the flexbook, in more courses at my college or university?

Strongly disagree

Disagree

Somewhat disagree

Neither agree or disagree

Somewhat agree

Agree

Strongly agree

Question 4

Why do you support or not support the $\$ 10 /$ credit hour student fee to encourage the development and adoption of OERs?

Question 5

If you have additional feedback on the idea of a $\$ 10$ /credit hour OER student fee that you'd like to provide, please use the space below.

*During the fall semester, Flat World Knowledge produced OER. That is no longer the case, but to keep the survey consistent this language wasn't changed in the spring surveys. 